\title{
Comparison of deoxynivalenol and zearaleone concentration in conventional and organic cereal products in western Poland
}

\author{
Kinga Mruczyk ${ }^{1, A-B, D \oplus}$, Małgorzata Mizgier ${ }^{1, E \oplus}$, Rafał W. Wójciak ${ }^{1,2, C \oplus}$, Angelika Cisek-Woźniak ${ }^{1, F \oplus}$ \\ ${ }^{1}$ Faculty of Physical Culture in Gorzów Wlkp. University of Physical Education, Poznan, Poland \\ ${ }^{2}$ Department of Clinical Psychology, University of Medical Sciences, Poznań, Poland \\ A - Research concept and design, B - Collection and/or assembly of data, C - Data analysis and interpretation, \\ $D$ - Writing the article, $E$ - Critical revision of the article, $F$ - Final approval of article
}

Mruczyk K, Mizgier M, Wójciak RW, Cisek-Woźniak A. Comparison of deoxynivalenol and zearaleone concentration in conventional and organic cereal products in western Poland. Ann Agric Environ Med. 2021; 28(1): 44-48. doi: 10.26444/aaem/116417

\begin{abstract}
I Abstract
Introduction and objective. Deoxynivalenol (DON, vomitoxin) and Zearalenone (ZEA) are mycotoxin contaminants of cereals and cereal products that pose a significant threat to food safety. The aim of the study was to investigate the occurrence of DON and ZEA in different organic and conventional unprocessed cereals and cereal products that are available on the Polish agricultural fields and market. A total of 78 unprocessed cereal and cereal product samples of organic and conventional production were sampled from agricultural fields situated in western Poland and from available on the Polish market packaged comercial products produced by different domestic manufacturers. All samples were analyzed for DON and ZEA by HPLC with fluorescence detection (HPLC-FLD).

Results. Co-occurrence of DON was detected in cereals from the organic production system, the average content was $285.25 \pm 134,04 \mathrm{\mu g} \mathrm{kg}^{-1}$ and from the conventional system $-373.71 \pm 171,20 \mu \mathrm{g} \mathrm{kg}^{-1}$, In flour from organic farming, the average DON content was $213.80 \pm 151,28 \mu \mathrm{g} \mathrm{kg}^{-1}$, in conventional flour the average was $336.29 \pm 188,90 \mathrm{\mu g} \mathrm{kg}^{-1}$. The range of DON concentrations in samples of cereal products from organic and conventional farms was detected in $26.3 \%$ and $31.6 \%$, whereas the average concentrations of DON in cereal products was $199.60 \pm 149.82 \mu \mathrm{g} \mathrm{kg}^{-1}$ and $387.67 \pm 250.24 \mathrm{ug} \mathrm{kg}^{-1}$, respectively. Conclusion. Mycotoxins contamination seen in organic cereals and cereal products does not statistical differ from that witnessed in their conventional counterparts.
\end{abstract}

I Key words

mycotoxins, ochratoxins A, zearalenone, contamnatins, cereal products, cereals

\section{INTRODUCTION}

Food contamination with mycotoxins is a public health threat [1]. Mycotoxins are regarded as priority food contaminants by the Global Environmental Monitoring System/WHO Monitoring Programme on Food Pollutants (GEMS/Food 1995) [2]. They are usually thermostable and tend to survive during the transformation and processing of contaminated plants, and are not usually eliminated during cooking and sterilization [3].

Several factors can affect the occurrence of mycotoxins: harvesting, storage, transport of grain, and agricultural technology, are some of the basic factors. Therefore, the right approach and actions in this area can significantly reduce mould growth, as well as affect the presence of mycotoxins [4]. Because of their ability to bind to plasma proteins, mycotoxins can persist in organisms if the exposure is repeated or chronic [5]. Due to the variety of chemical and biosynthetic structures, mycotoxins have innumerable biological effects and some of these are classified as carcinogenic, immunosuppressive or estrogenic, potentially causing serious metabolic disturbances in humans [6].

DON are highly toxic mycotoxins [7] and occur in basic food products and commonly consumed products, such as cereals, milk and dairy products, dried fruit and legumes,

Address for correspondence: Kinga Mruczyk, Poznan University of Physical Education, Faculty of Physical Culture in Gorzów Wlkp., Poland

E-mail:k.mruczyk@awf-gorzow.edu.pl

Received: 07.10.2019; accepted: 10.01.2020; first published: 06.02.2020 coffee, wine and beer [8]. The toxicological effects and diseases associated with exposure to DON have recently been investigated; however, epidemiological studies are required to critically examine the potential connection between the consumption of large quantities of DON and the incidence of gastro-enteritis and chronic diseases.

ZEA (Zearalenone) and its metabolites can be found worldwide in a range of cereals, including corn, sorghum, wheat, rice, barley and oats. ZEA may also be consumed as a result of ingesting meat, milk and eggs from animals exposed to these disease toxins, or which received ZEA to promote their growth. ZEA and its metabolites show strong estrogenic activity, hence it is often referred to as mycogen. ZEA plays an important role in increasing the risk of hormone-dependent cancers [9].

\section{MATERIALS AND METHOD}

During the 2014-2015 timeframe, a total of 78 samples were examined, of which 20 were unprocessed cereals (maize, wheat, oat, barley), and 58 were cereal-based products (flour, groats, pasta). Among them, 39 samples were declared to be organic (10 cereals and 29 cereal-based products), while 39 samples were produced in a conventional manner (10 cereals and 29 cereal products). During the harvesting period (July September) in 2014, unprocessed cereals were sampled from agricultural fields situated in western Poland. In 2015, cereal products were sampled in the form of packaged commercial 
products produced by different domestic manufacturers available on the Polish market.

Samples of organically produced products had been labeled in accordance with Regulation 834/2007/EC on organic production and labeling of organic products, which repeals Regulation (EEC) No. 2092/91 [10]. These products also contain the national or private organic producers' logo, the competent authority code and place of cultivation designation. Sampling and sample preparation were carried out in accordance with Commission Regulation 401/2006 [11] establishing sampling methods for the official control of mycotoxin levels in foodstuffs. Aggregate samples were taken of not less than $1 \mathrm{~kg}$, connecting the 3 primary samples (a minimum of $500 \mathrm{~g}$ of each sample). Samples were stored in a cool, dry place, and transported to the laboratory within 48 hours.

The prepared test portions were ground to a $1.0 \mathrm{~mm}$ fine powder using an analytical mill and then stored in plastic bags at $-4^{\circ} \mathrm{C}$ until analysis. The mycotoxins were isolated from cereals and cereal products using Donprep ${ }^{\oplus}$ and EASIEXTRAT Zearalenon ${ }^{\circledast}$ immunoaffinity columns by R-Biopharm Rhône for extracting mycotoxins in accordance with the manufacturer's procedures. The mycotoxins were analysed using high-performance liquid chromatography with fluorescence detection (HPLC-FLD).

Determination of DON and ZEA content. DON content was determined according to the National Institute of Hygiene Methodology - 'Determination of Fusarium toxins - deoxynivalenol (DON) in cereals and its products by highperformance liquid chromatography with purification using immunoaffinity columns'.

The principle of the method is to extract a sample with a mixture of polyethylene glycol and water. The centrifuged and filtered extract is purified and concentrated in immunoenzyme columns. After elution with methanol and water, the methanol/aqueous solution is evaporated to dryness and dissolved in $9.5 \%$ methanol. The solution is injected into the chromatographic column. The measurement is carried out at a wavelength of $220 \mathrm{~nm}$. The qualitative determination involves comparing the retention time of the standard and the sample tested. The quantitative determination involves reading the DON content in the test sample from the standard curve and making the appropriate calculation.

The DON content of the sample is expressed in $\mu \mathrm{g} \mathrm{kg}^{-1}$, calculated as:

$$
\mathrm{x}=\frac{\mathrm{cxV} 3 x \mathrm{~V} 2}{\mathrm{mxV} 1}
$$

$\mathrm{X}-\mathrm{DON}$ content in the product $[\mu \mathrm{g} / \mathrm{kg}]$;

$\mathrm{C}-\mathrm{DON}$ content read from the curve $[\mathrm{ng} / \mathrm{cm} 3]$;

V1 - volume applied on the enzyme-linked column [cm3]; V2 - volume of $9.5 \%$ methanol used to dissolve the residue after evaporation [ $\mathrm{cm} 3]$;

V3 - volume of extraction solvent [cm3] $\mathrm{m}$ - weight [g]. Detection limit (LOD) $-25 \mu \mathrm{g} / \mathrm{kg}$, limit of quantification (LQD) $-100 \mu \mathrm{g} / \mathrm{kg}$, average recovery $96 \%$, the measurement is made using a photodiode detector at a wavelength of $220 \mathrm{n}$.

Measurement conditions. The solution was injected on a RP Cl8 250 x $4.6 \mathrm{~mm}$ column, $5 \mu \mathrm{m}$, mobile phase composition: methanol 15\%: water $85 \%$, mobile phase flow $-1 \mathrm{~cm} 3 / \mathrm{min}$, injection volume $-100 \mu \mathrm{l}$, column temperature $-40^{\circ} \mathrm{C}$, autosampler temperature $-4^{\circ} \mathrm{C}$, wavelength $-220 \mathrm{~nm}$.
ZEA was determined according to the National Institute of Hygiene Methodology - Determination of Fusarium toxins zearalenon in cereals, and dairy products by high-performance liquid chromatography purification using immunoaffinity columns. The principle of the method is to extract the sample with $75 \%$ acetonitrile and water. The extract then filtered through filter paper, $20 \mathrm{~cm}^{3}$ of the filtrate removed and mixed with $80 \mathrm{~cm} 3$ of saline (PBS), and $\mathrm{pH} 7.4$ adjusted using $\mathrm{HCl}$ $(0.1 \mathrm{~mol} / \mathrm{l}) .25 \mathrm{~cm} 3$ of the solution was passed through a bed of EASIEXTRAT Zearalenon ${ }^{\circledast}$ enzyme immunoassays. Purification and concentration in the columns was performed according to R-Biopharm Rhône applications.

After elution, the acetonitrile-aqueous solution was injected into the chromatographic column. The ZEA quality assay consisted of comparing the retention time of the standard and the sample being tested, along with quantitative determination of the content of the mycotoxin tested in a sample from the standard curve the appropriate calculation was made.

ZEA content in the sample is expressed in $\mu \mathrm{g} \mathrm{kg}^{-1}$, calculated as:

$$
\mathrm{x}=\frac{\mathrm{cxV} 2 \mathrm{~V} 4 x \mathrm{~V} 5}{\mathrm{mxV} 1 \mathrm{xV} 3}
$$

$\mathrm{X}-\mathrm{ZEA}$ content in the product $\left[\mu \mathrm{g} \mathrm{kg}^{-1}\right]$;

C - ZEA content read from the calibration curve $\left[\mathrm{ng} / \mathrm{cm}^{3}\right]$;

$\mathrm{V} 1$ - volume of extract extracted $\left[\mathrm{cm}^{3}\right]$;

$\mathrm{V} 2$ - volume after dilution in PBS $\left[\mathrm{cm}^{3}\right]$;

$\mathrm{V} 3$ - volume applied to the affinity column $\left[\mathrm{cm}^{3}\right]$;

V4- volume of eluate from the enzyme-linked column $\left[\mathrm{cm}^{3}\right]$; $\mathrm{V} 5$ - volume of extraction solvent $\left[\mathrm{cm}^{3}\right]$;

$\mathrm{m}$ - weight $[\mathrm{g}]$.

Detection limit (LOD) - $5 \mu \mathrm{g} \mathrm{kg}^{-1}$, limit of quantification (LQD) - $10 \mu \mathrm{g} \mathrm{kg}^{-1}$, average recovery - 96; the measurement is made using a fluorescence detector and an excitation wave of $276 \mathrm{~nm}$, emission - $460 \mathrm{~nm}$.

Measurement conditions: RP C18 chromatographic column $250 \times 4.6 \mathrm{~mm}, 5 \mu \mathrm{m}$, mobile phase composition, acetonitrile $60 \%$ - water $40 \%$, mobile phase flow - $1 \mathrm{~cm} 3$ / min, injection volume $-100 \mu \mathrm{l}$, column temperature $-40^{\circ} \mathrm{C}$, autosampler temperature $-4^{\circ} \mathrm{C}$, emission wavelength $460 \mathrm{~nm}$, excitation wavelength $-276 \mathrm{~nm}$.

Statistical analysis. The results were analysed statistically using STATISTICA v.10 software. The difference in mycotoxin concentration in the groups was assessed using the Mann-Whitney test. Assumed statistical significance level $-\mathrm{p}<0.05$.

\section{RESULTS}

A total of 78 samples from organic and conventional systems were analyzed with HPLC. Occurrence of DON was detected in cereals from both production systems - organic and conventional. In cereals from the organic production system, the average content of DON was $285.25 \pm 134,04 \mu \mathrm{g} \mathrm{kg}^{-1}$ and was detected in $40 \%$ of the samples; range of contamination - 130-433 $\mu \mathrm{g} \mathrm{kg}^{-1}$. DON was detected in $70 \%$ of the cereal samples from conventional cultivation system, average content - 373.71 $\pm 171.20 \mu \mathrm{g} \mathrm{kg}^{-1}$, range of contamination $137-529 \mu \mathrm{g} \mathrm{kg}^{-1}$. 
In flour from organic farming, the average DON content was $213.80 \pm 151.28 \mu \mathrm{g} \mathrm{kg}^{-1}$ and detected in $50 \%$ of samples (range 104-459 $\mu \mathrm{g} \mathrm{kg}^{-1}$ ), in flour from conventional cultivation the average was $336.29 \pm 188.90 \mu \mathrm{g} \mathrm{kg}^{-1}$, level between $146-$ $646 \mu \mathrm{g} \mathrm{kg}^{-1}, 70 \%$ of the flour samples were contaminated with the test mycotoxin.

The range of DON concentrations in samples of cereal products from organic and conventional cultivation was $102.00-465.00 \mu \mathrm{g} \mathrm{kg}^{-1}$ and $137.00-792.00 \mu \mathrm{g} \mathrm{kg}-1$. It was detected in 26.3 and $31.6 \%$, whereas the average concentrations of DON in cereal products was $199.60 \pm 149,82 \mu \mathrm{g} \mathrm{kg}^{-1}$ and $387.67 \pm 250,24 \mu \mathrm{g} \mathrm{kg}^{-1}$ in samples of cereal products from organic and conventional cultivations (Tab. 1).

There was no ZEA presence in cereals from either organic or conventional cultivation. Only one sample of flour from conventional cultivation was found to contain ZEA. ZEA was also found in one sample of cereal products from organic cultivation and 3 samples from conventional cultivation. Furthermore, ZEA was detected in 5.3 and $15.8 \%$, whereas the average concentrations of ZEA in cereal products was $13,00 \mu \mathrm{g} \mathrm{kg}^{-1}$ and $14,45 \pm 2,76 \mu \mathrm{g} \mathrm{kg}$ in samples of cereal products from organic and conventional cultivations (Tab. 2).

\section{DISCUSSION}

Interest in organic food has increased worldwide in response to concerns about conventional farming practices, food safety, human health, animal welfare and the environment. In the EU, organic farming is an agricultural practice and modality of food production that combines favourable environmental and animal welfare standards and is supported by EU law $[12,10]$.

Today, many consumers prefer organic rather than conventional food because synthetic fungicides and mineral fertilizers are not used in organic production. It is generally believed that organic practices reduce the risk of plant infection [13], but at the same time there is an awareness that the worse use of fungicides may promote the presence of mycotoxins in 'natural' or 'home' chemicals - free products [14].

Data published insofar have shown that the presence of mycotoxins as frequent contaminants of different foodstuffs and feedstuffs greatly varies dependent on many parameters of influence, such as the type of cereal, weather conditions and among others $[15,16,17,18]$.

In this study, the occurrence of the mycotoxins in different unprocessed cereals cultivated in fields in Poland in an organic and conventional manner, and in cereal-based products available on the Polish market, was investigated. It was found that the average DON content was highest in samples of conventional cereal products and conventional flour - 387.67 and $336.29 \mu \mathrm{g} \mathrm{kg}^{-1}$ respectively. It should be noted that the highest level of the mycotoxin being tested was recorded in a sample of pasta from conventional grains $792 \mu \mathrm{g} \mathrm{kg}^{-1}$. This level exceeded the permissible limit specified in the regulation [19].

Malmauret et al. in France reported a co-occurrence of DON contamination of organic wheat was lower than that in conventional wheat (54.\% vs. $90.9 \%$, respectively), but the medium and maximum levels of this mycotoxin were 2-3 times higher in cereal grains from organic farming than in the conventional ( 250 vs. 80 and 494 vs. $215 \mu \mathrm{g} \mathrm{kg}^{-1}$, respectively) [20]. A study conducted in Germany between 1997-1998 [21] reported a greater contamination of DON wheat grains from organic farms. Malmauret et al. [20] noted that more 'conventional' seeds were contaminated, although at a low level, while organic grains were less often contaminated, although in a few cases at a high level.

DON has proved to be a more common mycotoxin in cereal grains than ZEA. Many authors confirm the frequent presence of DON in cereals grown both in Poland and in other parts of the world. DON contamination was noted in a large percentage of samples tested in Russia, the USA, Bulgaria, China and Hungary, ranging from 50\% - 96\% [22, $23,24]$. DON levels in cereal grains increase in years with frequent rainfall and high humidity; for example, there was less pollution of rye with DON in Bavaria in 2000 and 2001, especially in 2001 [25]; and in 2003, despite the presence of Fusarium graminearum, DON was observed in only $18.5 \%$ of infected grains.

In a study in the UK, including 247 samples produced organically and 1,377 samples conventionally produced wheat grain, no significant differences in DON content were found in grain from the 2 cultivation systems; an average DON level of $230 \mu \mathrm{g} / \mathrm{kg}$ was recorded for organic

Table 1. DON content in cereals, flour and cereal products $\left[\mu \mathrm{g} \mathrm{kg}^{-1}\right.$ ]

\begin{tabular}{|c|c|c|c|c|c|c|c|}
\hline \multirow{3}{*}{ Products } & \multicolumn{6}{|c|}{ DEOKSYNIVALENOL } & \multirow{3}{*}{$\begin{array}{c}\text { Test } \\
\text { Mann-Whitney } \\
\mathrm{p}\end{array}$} \\
\hline & \multicolumn{3}{|c|}{ Organic } & \multicolumn{3}{|c|}{ Conventional } & \\
\hline & No./\% of contaminated samples & $\overline{x x} \pm \mathrm{SD}$ & MIN-MAX & No./\% of contaminated samples & $\overline{x x} \pm \mathrm{SD}$ & MIN-MAX & \\
\hline Cereals & $4(10) ; 40 \%$ & $285.25 \pm 134.04$ & $130-433$ & $7(10) ; 70 \%$ & $373.71 \pm 171.20$ & $137-529$ & p0.2986 \\
\hline Flours & $5(10) ; 50 \%$ & $213.80 \pm 151.38$ & $104-459$ & $7(10) ; 70 \%$ & $336.29 \pm 188.90$ & $146-646$ & 0.1439 \\
\hline Cereal products & $5(19) ; 26,3 \%$ & $199.60 \pm 149.82$ & $102-465$ & $6(19) ; 31,6 \%$ & $387.67 \pm 250.24$ & $137-792$ & 0.1207 \\
\hline
\end{tabular}

Table 2. ZEA content in cereals, flour and cereal products [ $\left.\mu \mathrm{g} \mathrm{kg}^{-1}\right]$

\begin{tabular}{|c|c|c|c|c|c|c|c|}
\hline \multirow{3}{*}{ Products } & \multicolumn{6}{|c|}{ ZEARALENONE } & \multirow{3}{*}{$\begin{array}{c}\text { Test } \\
\text { Mann-Whitney } \\
\mathrm{p}\end{array}$} \\
\hline & \multicolumn{3}{|c|}{ Organic } & \multicolumn{3}{|c|}{ Conventional } & \\
\hline & No./\% of contaminated samples & $\overline{x x} \pm \mathrm{SD}$ & MIN-MAX & No./\% of contaminated samples & $\overline{x x} \pm \mathrm{SD}$ & MIN-MAX & \\
\hline Cereals & $0(10) ; 0 \%$ & & & $0(10) ; 0 \%$ & & & \\
\hline Flours & $0(10) ; 0 \%$ & & & $1(10) ; 10 \%$ & $10 \pm 0.0$ & $10-10$ & \\
\hline Cereal products & $1(19) ; 5.3 \%$ & $13 \pm 0.0$ & $13-13$ & $3(19) ; 15.8 \%$ & $14.45 \pm 2.76$ & $12.5-16.4$ & 0.9800 \\
\hline
\end{tabular}


substances and traditionally produced wheat [26]. That there are no differences in DON content in wheat from the 2 agricultural systems were also reported in studies of several other countries: France [27], Germany [28, 29], The Netherlands [30], Switzerland [31], Norway [32] and Spain [9]. The authors suggested that annual variability was more important for DON pollution than agricultural practices. The agricultural system did not affect DON contamination in 2010 in drier and warmer weather, significantly lower DON levels were found $(340 \mu \mathrm{g} / \mathrm{kg}$ for organic production and $460 \mu \mathrm{g} / \mathrm{kg}$ for traditionally produced wheat grain) [18]. Lower DON levels were found in organic than in traditionally produced wheat in studies from Italy [33, 34], Belgium [35], Slovakia [36] and Norway [15].

Higher DON concentrations in organic farming samples (average $599 \mu \mathrm{g} \mathrm{kg}^{-1}$ ) than in wheat from traditional agriculture (average $331 \mu \mathrm{g} \mathrm{kg}^{-1}$ ) were reported by Kirincic et al. [37]. A study of durum wheat from Italy reported lower levels of DON in organic than in conventionally produced grain [17]. However, in a Spanish study there was no difference in the content of DON in Durum wheat was detected in the 2 cultivation systems [16]. No differences were found in DON contamination in samples of barley grains produced by organic and conventional methods in Norway [15] and the UK [38]. In a study from Germany, there was no difference in the DON content of rye grain from two farming systems [39], while in Poland lower DON levels were found in organically produced rye than in conventional rye [40]. Most levels were well below the EU food limits [41]. Several authors have commented that weather conditions, crop year, location, crop rotation and tillage may be more important for the development of DON than crop type $[15,42,16,30,17,43,18]$.

This study showed that the average DON content was highest in cereal processed samples $\left(387.67 \mu \mathrm{g} \mathrm{kg}^{-1}\right)$, cereal grains (373.71 $\mu \mathrm{g} \mathrm{kg}^{-1}$ and flour (336.29 $\mu \mathrm{g} \mathrm{kg}^{-1}$ ) from conventional crops, compared to grains $\left(285.25 \mu \mathrm{g} \mathrm{kg}^{-1}\right)$, flour $\left(213.80 \mu \mathrm{g} \mathrm{kg}^{-1}\right)$ and cereal products $\left(199.60 \mu \mathrm{g} \mathrm{kg}^{-1}\right)$ from organic farming. The acceptable limit of DON concentration was exceeded in one sample from conventional crops, but not in any samples from organic products. No statistically significant differences were established in DON content found in cereals or cereal-based products of both types ( $p>0.05)$. Stanisławczyk et al. [44] observed that the average content of DON in cereals from conventional crops was the highest in grains $\left(127.95 \mu \mathrm{g} \mathrm{kg}^{-1}\right)$ and flour $\left(127.36 \mu \mathrm{g} \mathrm{kg}^{-1}\right)$, compared to samples of groats and oat flakes, and the content of this mycotoxin was on a similar level - about $0.90 \mu \mathrm{g} \mathrm{kg}^{-1}$. Studies by Mazurkiewicz et al. [45] did not show the permissible DON contents being exceeded in cereal grains. The average concentration of DON in cereal grains cultivated in the conventional manner was close to that obtained by Perkowski and Chełkowski [46] in studies carried out at the beginning of the 1990s. Birzele et al. [47] indicated greater contamination of DON grains from organic farming than conventional crops. Other studies carried out in Germany by the CVUA (Chemisches and Veterinaruntersuchungsamt Stuttgart) showed that the DON content in cereal products from organic farming was lower than in conventional farming products [48].

ZEA was not found in samples of the tested cereals. The current study shows the presence of ZEA in one sample of flour from conventional crops, and a significant difference in its occurrence in cereal products between two types of crops. The average ZEA content in cereal products was lower in organic farming products compared to conventional plant products $(\mathrm{p}<0.05)$. The maximum permissible ZEA content specified in the relevant European Regulation 1881/2006/EC was not exceeded in any of the products tested [19].

Stanisławczyk et al. [44] was also did not find that contamination levels were exceeded, and the ZEA content in the samples they tested was significantly lower than other mycotoxins content. The average content of mycotoxin in cereal products from conventional cultivation was $10 \mu \mathrm{g}$ $\mathrm{kg}^{-1}$. Much more varied results, although not exceeding the maximum levels, were obtained by Ghali et al. [49] who obtained different average ZEA contents in samples of wheat grains $-2.82 \mu \mathrm{g} \mathrm{kg}^{-1}$ and barley $-15 \mu \mathrm{g} \mathrm{kg}$ from conventional crops. Solarska et al. [50] detected ZEA in $68.2 \%$ of cereal products from organic farming. In the studies of LackoBartosova [36] and Vidal et al. [51], no differences were found in the content of ZEA between wheat produced by organic and conventional methods, while in wheat tests conducted by Meister in 2009 [43] showed lower concentrations of ZEA in samples from organic than in samples from conventional agriculture. In rye studies there was also no difference in ZEA concentration in samples from the 2 cultivation systems [40].

The relatively low sample number of studies, high variability, and the fact that ZEA is often below the detection level in a significant proportion of samples, reduces the possibility of statistical disclosure of the significant differences between organic and conventional agricultural practices.

\section{CONCLUSIONS}

In general, the mycotoxin contamination observed in organic cereals and cereal products does not differ significantly from what was observed in their conventional counterparts. It is likely that preventive measures used in organic farming are able to maintain mycotoxin contamination of organic cereals and organic cereal by-products at levels similar to those found in conventional cereals and cereal products, despite the fact that the fungicide is not handled. The findings of this study are important in terms of risk to human health, but they neither support nor reject the hypothesis that organic cereals are less contaminated than the conventional ones.

To reduce DON levels in products from organic and conventional farms, regular and increased monitoring supervising the most critical areas where DON contamination takes place, is required. In this respect, the control of preand post-harvest, storage and manufacturing processes, consisting of good agricultural practices, good storage practices, good manufacturing practices and hazard analysis critical control points, must abide within the standards of regulatory and monitoring organizations.

\section{REFERENCES}

1. JECFA, 2002. Evaluation of Certain Mycotoxins in Food: Fifty-sixth Report of the Joint FAO/WHO Expert Committee on Food Additives. WHO Technical Report Series No 906. WHO, Geneva, Switzerland

2. GEMS/Food-Euro. Reliable evaluation of low-level contamination of food, Report on workshop in the frame of GEMS/Food-Euro. Kulmbach (26-27 May 1995) (Germany): GEMS/Food-Euro, 1995, pp. 1-8.

3. Sirot V, Fremy JM, Leblanc JC. Dietary exposure to mycotoxins and health risk assessment in the second French total diet study. Food Chem. Toxicol. 2013; 52: 8481-11. 
4. Brodal G, Hofgaard IS, Eriksen GS, Bernhoft A, Sundheim L Mycotoxins in organically versus conventionally produced cereal grains and some other crops in temperate regions. World Mycotox J. 2016; 9: 755-770.

5. Galtier P, Loisaeu N, Oswald I, Paule PuelO. Toxicologie des mycotoxines: dangers et risques en alimentation humaine et animale [toxicology of mycotoxins: hazards and risks in human and animal food]. Academie veterinaire Veterinaire de France 2006; 59: 5-13.

6. Richard JL, Payne GA Desjardin AE, Maragos C, Norred WP, Pestka JJ, Philips TD, Van Egmond HP, Vardon PJ, Whitaker TB, Wood G. Mycotoxins Risks in Plant, Animal and Human Systems. CAST Task Force Report 139. Council for Agricultural Science and Technology, Ames, Iowa, USA, 2003, pp. 1-217.

7. Diaz DE. Mycotoxin Blue Book. Nottingham University Press, Thrumpton, Nottingham, UK. 2005, 349 pp.

8. Weidenborner M. Mycotoxins in Foodstuffs. Springer, New York, 2008, pp. 1-503.

9. Withanage GS, Murata H, Koyama T, Ishiwata I. Agonistic and antagonistic effect of zearalenone, an estrogenic mycotoxin, on SKN, HHUA, and HepG2 human cancer cell lines. Vet Hum Toxicol. 2001; 43: 6-10.

10. Council Regulation 834 (2007) /EC of 28 June 2007 on organic production and labelling of organic products and repealing Regulation (EEC) No 2092/91. Off J Eur Union L189: 1-23.

11. Commission Regulation (EC) No 401 (2006) of 23 February 2006 laying down themethods of sampling and analysis for the official control of the levels of mycotoxins in foodstuffs. Off J Eur Union L70: 12-34.

12. Commission Regulation 889 (2008) EC of 5 September 2008 layingdown detailed rules for the implementation of Council Regulation (EC) No $834 / 2007$ on organic production and labelling of organic products with regard to organic production, labelling and control. Off J Eur Union L250: 1-115.

13. Juan C, Moltó JC, Lino CM, Mañes J Determination of ochratoxin A in organic and non-organic cereals and cereal products from Spain and Portugal. Food Chem. 2008; 107: 525-530.

14. Pussemier L, Pierard JY, Anselme M, Tagni EK, Motte JC, Larondelle Y. Development and application of analyticalmethods for the determination of mycotoxins in organic and conventional wheat. Food Additives and Contaminants. 2006; 23: 1208-1218.

15. Bernhoft A, Clasen PE, Kristoffersen AB, Torp M. Less Fusarium infestation and mycotoxin contamination in organic than in conventional cereals. Food Additives and Contaminants Part A. 2010; 27: 842-852.

16. Gimenez I, Escobar J, Ferruz E, Loran S, Herrera M, Juan T, Herrera A Arino A. The effect of weather and agronomic practice on deoxynivalenol mycotoxin in durum wheat. J Life Sci. 2012; 6: 513-517.

17. Quaranta F, Amoriello T, Aureli G, Belocchi A, D’Egidio, MG, Fornara M, Melloni S, Desiderio E. Grain yield, quality and deoxynivalenol (DON) contamination of durum wheat (Triticum durum Desf.): results of national networks in organic and conventional cropping systems. 2010; 5(4).

18. Munger H, Vanasse A, Rioux S, Légere A. Bread wheat performance, fusarium head blight incidence and weed infestation response to lowinput conservation tillage systems in eastern Canada. Can J Plant Sci. 2014; 94: 193-201.

19. Commission Regulation (EC) No 1881 (2006) of 19 December 2006 setting maximum levels for certain contaminants in foodstuffs. Off J Eur Union L364: 5-24.

20. Malmauret L, Parent-Massin D, Hardy JL, Verger P. Contaminants in organic and conventional foodstuffs in France. Food Addit Contam. 2002; 19: 524-532.

21. Birzele B, Meier A, Hindorf H, Kramer J, Dehne, HW. Epidemiology of Fusarium infection and deoxynivalenol content in winter wheat in the Rhineland, Germany. Eur J Plant Pathol. 2002; 108: 667-673.

22. Arseniuk E, Chełkowski J, Foremska E, Góral T. Fusarium Head Blight Reactions and Accumulation of Deoxynivalenol (DON) and Some of its Derivatives in Kernels of Wheat, Triticale and Rye. J Phytopathol. 1999; 147: 466-489.

23. Büttner P. Das Artenspektrum der Gattung Fusarium an Weizen und Roggen in Bayern in des Jahren 2003 und 2004, Gesunde Pflanzen. 2006; 58: 28-33.

24. Perkowski J. Badania zawartości toksyn fuzaryjnych w ziarnie zbóż. Rozprawy Naukowe Rocznik AR w Poznaniu. 1999; 295: 11-34.

25. Berg T, Ghorbani F, Rasmussen PH. Deoxynivalenol and other Fusarium toxins in wheat and rye flours on the Danish market, Food Additives and Contaminants. 2003; 20(4): 396-404.

26. Edwards SG. Fusarium mycotoxin content of UK organic and conventional wheat. Food Additives and Contaminants Part A 2009b; 26: $496-506$
27. Champeil A, Fourbet JF, Dore T, Rossignol L. Influence of cropping system on Fusarium head blight and mycotoxin levels in winter wheat. Crop Protection. 2004; 23: 531-537.

28. Berleth M, Backes F, Kramer J. Schimmelpilzspektrum und Mycotoxine (Deoxynivalenol und Ochratoxin A) in Getreideproben aus okologischem und integrierten Anbau. Agribiological Research. 1998; 51: 369-376.

29. Marx H, Gedek B, Kollarczik B. Vergleichende untersuchungen zum mykotoxikologischen status von okologisch und konventionell angebautem getreide. Zeitschrift fur Lebensmittel- Untersuchung undForschung. 1995; 201: 83-86.

30. Hoogenboom LAP, Bokhorst G, Northolt MD, Vijer LVD, Broex, NJG, Mevius, DJ, Meijs, JAC and Roest, JVD. Contaminants and microorganisms in Dutch organic food products; comparison with conventional products. Food Additives and Contaminants Part A. 2005; 25: 1195-1207.

31. Mader P, Hahn D, Dubois, D, Gunst L, Alfoldi, T Bergmann, H, Oehme M, Amado R, Schneider H, Graf U, Velimirov A, Fliessbach A, Niggli $\mathrm{U}$. Wheat quality in organic and conventional farming: results of a 21 year field experiment. J Sci Food Agric. 2007; 87: 1826-1835.

32. Eltun R. The Apelsvoll cropping system experiment, III. Yield and grain quality of cereals. Norwegian J Agric Sci. 1996; 10: 7-22.

33. Cirillo T, Ritieni A, Visone M, Cocchieri RA. Evaluation of conventional and organic Italian foodstuffs for deoxynivalenol and fumonisins B1 and B2. J Agric Food Chem. 2003; 51: 8128-8131.

34. Rossi F, Bertuzzi T, Comizzoli S, Turconi G, Roggi C, Pagani M, Cravedi P, Pietri A. Preliminary survey on composition and quality of conventional and organic wheat. Italian J Food Sci. 2006; 18: 355-366.

35. Pussemier L, Larondelle Y, Van Peteghem C, Huyghebaert A. Chemical safety of conventionally and organically produced foodstuffs: a tentative comparison under Belgian conditions. Food Cont. 2006; 17: 14-2.

36. Lacko-Bartosova M, Kobida L. Deoxynivalenol and zearalenone in winter wheat grown in ecological and integrated systems. Res J Agric Sci. $2011 ; 43: 68-72$.

37. Kirincic S, Skrjanc B, Kos N, Kozolc B, Pirnat N, Tavcar- Kalcher G. Mycotoxins in cereals and cereal products in Slovenia - official control of foods in the years 2008-2012. Food Control 2015; 50: 157-165.

38. Edwards SG. Fusarium mycotoxin content of UK organic and conventional barley. Food Additives and Contaminants Part A 2009c; 26: $1185-1190$.

39. Doll S, Valenta H, Danicke S, Flachowsky G. Fusarium mycotoxins in conventionally and organically grown grain from Thuringia/Germany. Landbauforschung Volkenrode. 2002; 2(52): 91-96.

40. Blajet-Kosicka A, Twaruzek M, Kosicki R, Sibiorowska E, Grajewski J. Cooccurrence and evaluation of mycotoxins in organic and conventional rye grain and grain products. Food Control. 2014; 38: 61-66.

41. European Commission (EC). Commission Regulation (EC) no. $1881 / 2006$ setting maximum levels for certain contaminants in foodstuffs. Official Journal of the European Union L 2006; 364: 5-24.

42. De Galarreta JIR, Butron A, Ortiz-Barredo A, Malvar RA, Ordas A, Landa A, Revilla P. Mycotoxins in maize grains grown in organic and conventional agriculture. Food Control 2015; 52: 98-102.

43. Meister U. Fusarium toxins in cereals of integrated and organic cultivation from the Federal State of Brandenburg (Germany) harvested in the years 2000-2007. Mycotoxin Research. 2009; 25: 133-139.

44. Stanisławczyk R, Rudy M, Świątek B. Występowanie mikotoksyn w zbożach i przetworach zbożowych znajdujących się w placówkach handlowych województwa podkarpackiego. Żywność. Nauka. Technologia. Jakość. 2010; 6(73): 58-66.

45. Mazurkiewicz J, Solarska E, Kuzdraliński A, Muszyńska M. The occurrence of fusarium toxins in winter wheat depending on fertilization. J Res Appl Agric Engineering. 2008; 15, 53(4).

46. Perkowski J, Chełkowski J. Porównanie zawartości deoksyniwalenolu i 3 -acetylodeoksyniwalenolu w naturalnie porażonej pszenicy w latach 1986-1988. Post Nauk Roln. 1993; 242(2): 83-89.

47. Birzele B, Prange, A, Krämer, J. Deoxynivalenol and ochratoxin A in German wheat and changes of levels in relation to storage parameters. Food Addit Contam. 2000; 17: 1035-1039.

48. Gutmacher B, Lauber U, Schnaufer R. Oekomonitoring, CVUA Stuttgart.

49. Ghali R, Hmaissia-khlifa K, Ghorbel H, Maaroufi K, Hedili A. Incidence of aflatoxins, ochratoxin A and zearalenone in Tunisian foods. Food Control. 2008; 19: 921-924.

50. Solarska E, Marzec M. Mycotoxins in cereal products from organic cultivation. J Res Appl Agric Engineering. 2012; 57 (4).

51. Vidal A, Marin S, Ramos AJ, Cano-Sancho G, Sanchis V. Determination of aflatoxins, deoxynivalenol, ochratoxin A and zearalenone in wheat and oat based bran supplements sold in the Spanish market. Food Chem Toxicol. 2013; 53: 133-138. 